\title{
Laboratory evidence of organic peroxide and peroxyhemiacetal formation in the aqueous phase and implications for aqueous $\mathrm{OH}$
}

\author{
Y. B. Lim $^{1, \mathrm{a}}$ and B. J. Turpin ${ }^{2}$ \\ ${ }^{1}$ Department of Environmental Sciences, Rutgers University, New Brunswick, NJ, USA \\ ${ }^{2}$ Department of Environmental Science and Engineering, University of North Carolina, Chapel Hill, NC 27599, USA \\ ${ }^{a}$ now at: Center for Environmental, Health and Welfare Research, Korea Institute of Science and Technology, \\ Seoul, Republic of Korea
}

Correspondence to: Y. B. Lim (ylim@kist.re.kr)

Received: 29 May 2015 - Published in Atmos. Chem. Phys. Discuss.: 25 June 2015

Revised: 13 November 2015 - Accepted: 13 November 2015 - Published: 19 November 2015

\begin{abstract}
Aqueous chemistry in atmospheric waters (e.g., cloud droplets or wet aerosols) is considered a potentially important atmospheric pathway to produce secondary organic aerosol $\left(\mathrm{SOA}_{\mathrm{aq}}\right)$. Water-soluble organic compounds with small carbon numbers $\left(\mathrm{C}_{2}-\mathrm{C}_{3}\right)$ are precursors for $\mathrm{SOA}_{\mathrm{aq}}$; products include organic acids, organic sulfates, and highmolecular-weight compounds/oligomers. Fenton reactions and the uptake of gas-phase $\mathrm{OH}$ radicals are considered to be the major oxidant sources for aqueous organic chemistry. However, the sources and availability of oxidants in atmospheric waters are not well understood. The degree to which $\mathrm{OH}$ is produced in the aqueous phase affects the balance of radical and non-radical aqueous chemistry, the properties of the resulting aerosol, and likely its atmospheric behavior.

This paper demonstrates organic peroxide formation during aqueous photooxidation of methylglyoxal using ultrahigh-resolution Fourier transform ion cyclotron resonance electrospray ionization mass spectrometry (FTICR-MS). Organic peroxides are known to form through gas-phase oxidation of volatile organic compounds. They contribute secondary organic aerosol (SOA) formation directly by forming peroxyhemiacetals and epoxides (i.e., IEPOX), and indirectly by enhancing gas-phase oxidation through $\mathrm{OH}$ recycling. We provide simulation results of organic peroxide/peroxyhemiacetal formation in clouds and wet aerosols and discuss organic peroxides as a source of condensedphase $\mathrm{OH}$ radicals and as a contributor to aqueous SOA.
\end{abstract}

\section{Introduction}

Secondary organic aerosol (SOA) is a major component of atmospheric fine particulate matter $\left(\mathrm{PM}_{2.5}\right)$ (Zhang et al., 2007), contributes to adverse health, and affects climate by scattering (Seinfeld and Pandis, 1998) and sometimes by absorbing solar radiation (e.g., "brown carbon") (Andreae and Gelencser, 2006; Bones et al., 2010; Zhang et al., 2011). Although the chemical and physical properties of aerosols are needed to predict effects, the properties of SOA are poorly understood because SOA formation itself is poorly understood. Aqueous chemistry in atmospheric waters (e.g., cloud droplets or wet aerosols) is a potentially important pathway to produce SOA ( $\mathrm{SOA}_{\mathrm{aq}}$; Blando and Turpin, 2000) and could be comparable in magnitude to "traditional" SOA, formed via partitioning of semivolatile organic products of gas-phase oxidation $\left(\mathrm{SOA}_{\text {gas }}\right.$ ) globally (Liu et al., 2012a; Lin et al., 2012; Henze et al., 2008) and in locations where relative humidity and aerosol hygroscopicity are high (Carlton and Turpin, 2013; Carlton et al., 2008; Fu et al., 2008; Chen et al., 2007). Because $\mathrm{SOA}_{\mathrm{aq}}$ is formed from small water-soluble precursors with high $\mathrm{O} / \mathrm{C}$ ratios, it forms SOA (e.g., oligomers, organic salts) with high $\mathrm{O} / \mathrm{C}$ ratios and may explain the highly oxygenated nature of atmospheric organic aerosols, while $\mathrm{SOA}_{\text {gas }}$ is less oxygenated (Aiken et al., 2008; Lim et al., 2010, 2013).

$\mathrm{OH}$ radicals are important oxidants in clouds. In the high solute concentrations in wet aerosols, however, besides $\mathrm{OH}$ radical reactions a more complex system of organic radical and non-radical reactions occurs (Lim et al., 2010; McNeill 
et al., 2012; Ervens et al., 2014). Thus, an understanding of the availability of $\mathrm{OH}$ radicals is important to assessing the relative importance of radical and non-radical chemistry in aerosols. The uptake of gas-phase $\mathrm{OH}$ radicals into atmospheric waters (Faust and Allen, 1993) and Fenton reactions in the condensed/aqueous media (Arakaki and Faust, 1998) are considered the major oxidant sources for aqueous organic chemistry. Oxidant sources in organic-containing clouds, fog and aerosol waters, and oxidant reactions with dissolved organic compounds have been documented (Arakaki et al., 2013; Weller et al., 2014; Long et al., 2013). Depending on sources of $\mathrm{OH}$ radicals, aqueous oxidation reactions can exhibit a surface area dependence (e.g., controlled by $\mathrm{OH}$ uptake) or a volume dependence (e.g., controlled by $\mathrm{OH}$ production through aqueous chemistry; Ervens et al., 2014). Herein, we explore the hypothesis that organic peroxides produce $\mathrm{OH}$ radicals within the atmospheric aqueous phase; we also demonstrate the formation of organic peroxides in the aqueous phase and their contribution to condensed-phase chemistry.

Organic peroxides (herein particularly organic hydroperoxides - ROOH) are known to play an important role in gas-phase chemistry. They are commonly found in the atmosphere with mixing ratios of $0.1-1$ ppb (Lee et al., 1993, 2000; De Serves et al., 1994; Sauer et al., 2001; Grossmann et al., 2003; Guo et al., 2014). They are known to form through gas-phase reactions of volatile organic compounds (VOCs) with $\mathrm{OH}$ radicals, $\mathrm{NO}_{3}$ radicals and $\mathrm{O}_{3}$ (Atkinson and Arey, 2003). While their chemistry is not fully understood, these atmospheric organic species are "key" to peroxy radical/ $\mathrm{NO}_{x}$ chemistry (Dibble, 2007; Glowacki et al., 2012), lead to photochemical smog formation, are important to the $\mathrm{HO}_{x}-\mathrm{NO}_{x}-\mathrm{O}_{3}$ balance (Wennberg et al., 1998; Singh et al., 1995), contribute to $\mathrm{O}_{3}$ formation or depletion in the upper troposphere, and form SOA (Tobias and Ziemann, 2000; Ehn et al., 2014). Organic peroxides (formed from gas-phase ozonolysis of monoterpenes, e.g., $\alpha$ - and $\beta$-pinenes) are major constituents of SOA (Docherty et al., 2005). Monoterpenes have a global emission second only to isoprene among non-methane VOCs and may be the most efficient $\mathrm{SOA}_{\text {gas }}$ precursor class (Kanakidou et al., 2005). Organic peroxides contribute to organic aerosol by forming peroxyhemiacetal oligomers with atmospherically abundant organic carbonyls (e.g., aldehydes and ketones) via acid catalysis in aerosols (Tobias and Ziemann, 2000; Ziemann, 2002). In general, due to the characteristically weak $\mathrm{O}-\mathrm{O}$ bonds of organic peroxides, the gas-phase decomposition of organic peroxides through photolysis or intermolecular radical reactions recycles $\mathrm{OH}$ radicals and can enhance gas-phase photooxidation of atmospheric organic compounds. Recent field studies demonstrate that gas-phase $\mathrm{OH}$ recycling enhances isoprene photooxidation (Paulot et al., 2009; Taraborrelli et al., 2012). And a recent lab study (Badali et al., 2015) demonstrates that $\mathrm{OH}$ radicals are photolytically formed from the solutions of SOA from terpene ozonolysis and that $\mathrm{OH}$ formation is likely due to photolysis of organic peroxides.

Organic peroxides are known to be moderately water soluble (Henry's law constant up to $1000 \mathrm{M} \mathrm{atm}^{-1}$ ). They are present in rainwater with concentrations of $0.1-10 \mu \mathrm{M}$ (Lind and Kok, 1986; Hellpointer and Gab, 1989; Liang et al., 2013), presumably by uptake from the gas phase. Badali et al. (2015) measured $\mathrm{OH}$ radical formation from photolysis of terpene-ozone SOA solutions and organic peroxide standard solutions ( $t$-butyl hydroperoxide and cumene hydroperoxide). However, photolysis of the terpene SOA generates twice as much $\mathrm{OH}$ as is generated from a comparable amount of organic peroxide alone (i.e., standards). Since there should exist plenty of aldehydes formed from ozone reactions, we argue that organic peroxides could also be formed in the SOA solution during the photolytic experiments. In this work, we show that organic peroxides are also produced from aqueousphase $\mathrm{OH}$ oxidation. We identify organic peroxide products from methylglyoxal and acid-catalyzed oligomers (i.e., peroxyhemiacetals formed with methylglyoxal) by ultra-highresolution mass spectrometry. We simulate organic peroxide and peroxyhemiacetal formation under atmospheric conditions and explore organic peroxide contributions to aqueousphase $\mathrm{OH}$ production and to $\mathrm{SOA}_{\mathrm{aq}}$ formation.

\section{Experimental section}

\subsection{Cuvette chamber reactions}

Reactions of methylglyoxal with $\mathrm{OH}$ radicals in the aqueous phase were conducted in a cuvette chamber, which holds 10 cuvettes ( $3 \mathrm{~mL}$ each; Spectrocell) equidistant from a $254 \mathrm{~nm}$ Hg UV lamp (Strahler). Cuvettes were immersed in a water bath to maintain the temperature at $25^{\circ} \mathrm{C}$. In each cuvette, $10 \mathrm{mM}$ of methylglyoxal (Sigma-Aldrich) was dissolved in $18 \mathrm{M} \Omega$ Mili-Q water. $\mathrm{OH}$ radicals $\left(10^{-13}\right.$ $10^{-12} \mathrm{M}$ ) were generated in each cuvette by photolysis of $20 \mathrm{mM}$ of $\mathrm{H}_{2} \mathrm{O}_{2}$ (Sigma-Aldrich) with the rate constant of $5.58 \times 10^{-5} \mathrm{M} \mathrm{s}^{-1}$. The $\mathrm{H}_{2} \mathrm{O}_{2}$ photolysis rate constant was determined from $\mathrm{H}_{2} \mathrm{O}_{2}+\mathrm{UV}$ control experiments conducted in the same cuvette chamber as described previously (Tan et al., 2010) and corrected for light absorption by $\mathrm{H}_{2} \mathrm{O}_{2}$ (Lim et al., 2013). Liu et al. (2012b) and Zhao et al. (2013) found that $\alpha$-hydroperoxides can form when methylglyoxal reacts with hydrogen peroxide in the dark. However, this reaction cannot explain the formation of the identified peroxyhemiacetals in this work $\left(\mathrm{PHA}_{1}\right.$ and $\left.\mathrm{PHA}_{2}\right)$ since the molecular weight of the $\alpha$-hydroperoxide is different from those of $\mathrm{R}_{1} \mathrm{OOH}$ and $\mathrm{R}_{2} \mathrm{OOH}$. Moreover, according to control experiments by Tan et al. (2010) methylglyoxal degradation is much slower with hydrogen peroxide in the dark than it is with hydrogen peroxide in the UV light. Therefore, we do not expect the formation of the $\alpha$-hydroperoxide in our photooxidation experiment. 


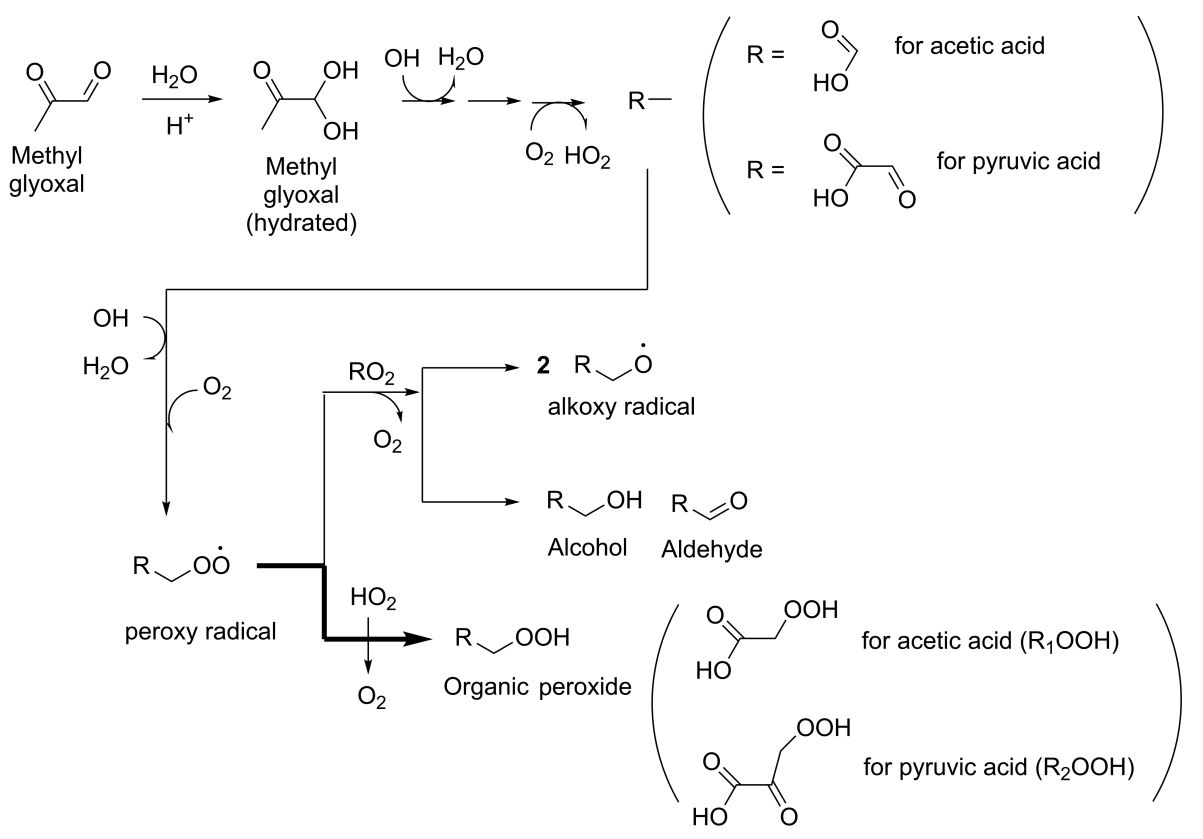

Figure 1. Organic peroxide formation from aqueous-phase $\mathrm{OH}$ radical reactions of methylglyoxal.

The $\mathrm{OH}$ radical concentrations were estimated via modeling (Lim et al., 2013). It should be noted that using $20 \mathrm{mM}$ of $\mathrm{H}_{2} \mathrm{O}_{2}$ and the $254 \mathrm{~nm}$ UV lamp was not intended to simulate tropospheric photolysis, rather to provide a source of $\mathrm{OH}$ radicals. According to our previous control experiments (i.e., methylglyoxal $+\mathrm{UV}$; methylglyoxal $+\mathrm{H}_{2} \mathrm{O}_{2}$ ), small amounts of pyruvic, acetic and formic acids form slowly in control experiments. However, dicarboxylic acids, the major products, did not form in the absence of $\mathrm{OH}$ radicals (i.e., in control experiments; Tan et al., 2010). Photooxidation of methylglyoxal was allowed to proceed for $1 \mathrm{~h}$. After being removed from the chamber, the cuvettes were kept frozen until analysis. No catalase was added in order to preserve organic peroxide products.

\subsection{Organic peroxide and peroxyhemiacetal analysis}

An ultra-high-resolution Fourier transform ion cyclotron resonance electrospray ionization mass spectrometer (FTICRMS; Thermo-Finnigan LTQ-XL, Woods Hole Oceanographic Mass Spectrometer Facility) was used to determine the elemental composition of organic products as described previously (Altieri et al., 2008; Tan et al., 2012). The capillary voltage and a capillary temperature were $-30.00 \mathrm{~V}$ and $300^{\circ} \mathrm{C}$, respectively, for negative-mode analyses. Positivemode analyses were conducted with a capillary voltage of $20.00 \mathrm{~V}$ and a capillary temperature of $260^{\circ} \mathrm{C}$. Both FTICRMS and FTICR-MS/MS were used to analyze organic peroxide products from aqueous photooxidation of methylglyoxal and a standard solution, which was prepared by adding $10 \mathrm{mM}$ of tert-butyl hydroperoxide (Sigma-Aldrich) and $10 \mathrm{mM}$ of methylglyoxal (Sigma-Aldrich). These samples were diluted 100-fold with water (by volume) and diluted again with methanol $(\mathrm{MeOH}) 2$-fold (by volume). Thus, the mobile phase consisted of $50 \%$ water and $50 \% \mathrm{MeOH}$; $0.1 \%$ of formic acid (by volume) was also added. These diluted samples were immediately introduced into the elec-

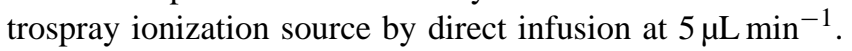
Photooxidation products of methylglyoxal were expected in both negative and positive modes due to a carboxylic group (negative mode) and a hydroxyl group (positive mode) in their structure (Table 1), whereas tert-butyl hydroperoxide is found only in the positive mode.

\section{Organic peroxide chemistry}

We hypothesize that aqueous-phase $\mathrm{OH}$ radical reactions of methylglyoxal lead to organic peroxide formation as shown in Fig. 1. OH radical reactions are initiated by $\mathrm{H}$-atom abstraction. Subsequent $\mathrm{O}_{2}$ addition and $\mathrm{HO}_{2}$ decomposition mainly lead to the formation of pyruvic acid and acetic acid (Lim et al., 2013). Both pyruvic and acetic acid react further with $\mathrm{OH}$ radicals and $\mathrm{O}_{2}$, forming peroxy radicals $\left(\mathrm{RO}_{2}\right)$, which undergo bimolecular $\mathrm{RO}_{2}-\mathrm{RO}_{2}$ reactions (Lim et al., 2013). However, substantial amounts of peroxy radicals could also react with $\mathrm{HO}_{2}$, forming organic peroxides (as indicated by a bold arrow), since $\mathrm{HO}_{2}$ is a common byproduct of aqueous photooxidation (Lim et al., $2010,2013)$ and is also water soluble (Henry's law constant $=4 \times 10^{3} \mathrm{M} \mathrm{atm}^{-1}$; this is $\sim 100$ times higher than that of $\mathrm{OH}$ radicals).

We further expect organic peroxides to form peroxyhemiacetals with aldehydes via acid catalysis in the aqueous phase 
Table 1. FTICR-MS and theoretical readings for methylglyoxal, organic peroxides and peroxyhemiacetals.

\begin{tabular}{|c|c|c|}
\hline Organic compound & Theoretical reading $^{\mathrm{a}}$ & FTICR-MS reading \\
\hline \multirow{3}{*}{$\begin{array}{c}\text { O O } \\
\text { Methylglyoxal } \\
\text { MW 72.02113 }\end{array}$} & $\begin{array}{c}\underset{\left.\mathrm{MO}+\mathrm{MeOH}^{\mathrm{b}}+\mathrm{Na}\right]^{+}}{=127.03715} \\
=1\end{array}$ & $\mathrm{~m} / \mathrm{z}^{+} 127.03666$ \\
\hline & $\begin{array}{c}\mathrm{HO}_{\left[\mathrm{M}+\mathrm{H}_{2} \mathrm{O}+\mathrm{MeOH}^{\mathrm{OH}}+\mathrm{Na}^{+}\right.}^{\mathrm{MeO}} \\
=145.04768 \\
\mathrm{OOH}\end{array}$ & $m / z^{+} 145.04714$ \\
\hline & $\begin{aligned} & \mathrm{MeO}_{\mathrm{HO}}^{c} \substack{\mathrm{OMe} \\
c} \\
& {\left[\mathrm{M}+2 \mathrm{MeOH}^{\mathrm{b}}+\mathrm{Na}^{+}=159.06330\right.}\end{aligned}$ & $m / z^{+} 159.06278$ \\
\hline $\begin{array}{c}\text { F } \\
\text { t-butyl hydroperoxide } \\
\text { MW } 90.06809\end{array}$ & {$[\mathrm{M}+\mathrm{Na}]^{+}=113.05786$} & $m / z^{+}$(not detected) \\
\hline $\begin{array}{l}\mathrm{HO} \\
\mathrm{R}_{1} \mathrm{OOH} \\
\text { MW } 92.01096\end{array}$ & {$[\mathrm{M} \mathrm{H}]^{-}=91.00314$} & $m / z^{-}$(not detected) \\
\hline $\begin{array}{c}\mathrm{HO} \quad \\
\mathrm{R}_{2} \mathrm{OOH} \\
\mathrm{MW} 120.00588\end{array}$ & {$[\mathrm{M}-\mathrm{H}]^{-}=118.99805$} & $m / z^{-}$(not detected) \\
\hline $\begin{array}{c}\text { HO } \\
\text { PHA }_{\text {std }} \\
\text { MW } 162.08922\end{array}$ & {$[\mathrm{M}+\mathrm{Na}]^{+}=185.07899$} & $m / z^{+} 185.07797$ \\
\hline 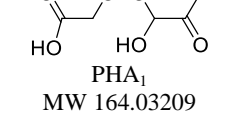 & $\begin{array}{l}{[\mathrm{M}-\mathrm{H}]^{-}=163.02427} \\
{[\mathrm{M}+\mathrm{Na}]^{+}=187.02186}\end{array}$ & $\begin{array}{l}m / z^{-} 163.02405 \\
m / z^{+} 187.02069\end{array}$ \\
\hline$\underset{\mathrm{HO}}{\mathrm{MW} 192.02701}$ & $\begin{array}{l}{[\mathrm{M}-\mathrm{H}]^{-}=191.01918} \\
{[\mathrm{M}+\mathrm{Na}]^{+}=215.01678}\end{array}$ & $\begin{array}{l}m / z^{-} 191.01998 \\
m / z^{+} 215.01565\end{array}$ \\
\hline
\end{tabular}

a Theoretical reading is based on actual atomic/molecular weights obtained by online software, "Molecular Isotopic Distribution Analysis (MIDAs)" (http://www.ncbi.nlm.nih.gov/CBBresearch/Yu/midas/index.html). ${ }^{b} \mathrm{MeOH}$ : methanol. Note that the mobile phase contains $50 \%$ water (with $0.05 \%$ formic acid) and $50 \% \mathrm{MeOH}$. ${ }^{c} \mathrm{MeO}$ is a deprotonated $\mathrm{MeOH}$.

(Fig. 2a), as they do in dry aerosols (Tobias and Ziemann, 2000; Docherty et al., 2005). Below we document the formation of peroxyhemiacetals from a commercially available organic peroxide, tert-butyl hydroperoxide and methylglyoxal in aqueous solution (Fig. 2b). Then we argue that organic peroxide products $\left(\mathrm{R}_{1} \mathrm{OOH}\right.$ and $\mathrm{R}_{2} \mathrm{OOH}$ in Fig. 1) from the aqueous $\mathrm{OH}$ oxidation of methylglyoxal react further with methylglyoxal in water to produce peroxyhemiacetals. Briefly, a carbonyl group (aldehyde) in methylglyoxal is protonated by $\mathrm{H}^{+}$; then a hydroperoxyl group $(-\mathrm{OOH})$ attacks a protonated carbonyl group, forming peroxyhemiac- etal. This peroxyhemiacetal chemistry is a well-established oligomerization mechanism for SOA from gas-phase ozone reactions of alkenes in smog chamber studies (Tobias and Ziemann, 2000). In the Tobias and Ziemann study, organic peroxides are first formed in the gas phase and become particles through gas-particle partitioning. Then organic peroxides form peroxyhemiacetals with by-product aldehydes through acid-catalyzed heterogeneous reactions on the particle surface. In current study, the detection of peroxyhemiacetals in our aqueous chemistry experiments (see below) pro- 
(a)

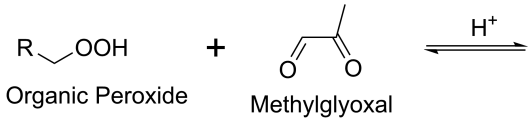

(b)

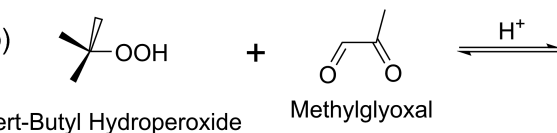

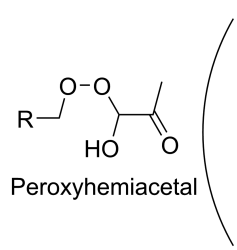

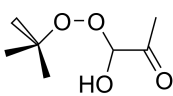

Peroxyhemiacetal for standard $\left(\mathrm{PHA}_{\text {std }}\right)$

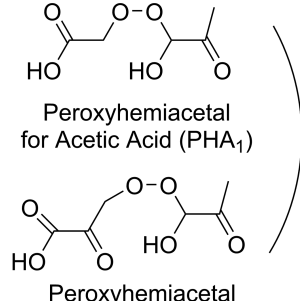

for Pyruvic Acid $\left(\mathrm{PHA}_{2}\right)$

Figure 2. Acid-catalyzed peroxyhemiacetal formation from a precursor, methylglyoxal, with organic peroxide products of aqueous photooxidation (a) and from methylglyoxal with tert-butyl hydroperoxide in standard solutions (b).

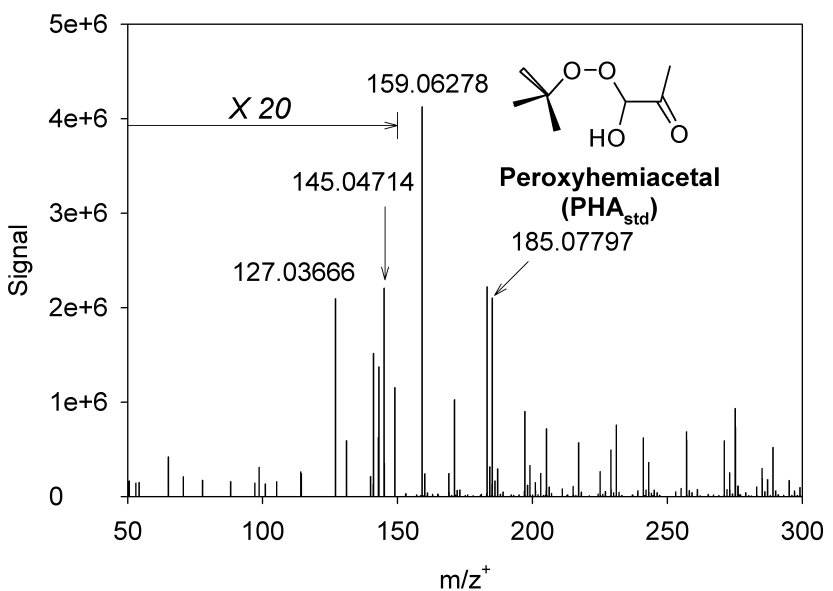

Figure 3. A full FTICR-MS spectrum for the standard solution of methylglyoxal $(10 \mathrm{mM})$ and tert-butyl hydroperoxide $(10 \mathrm{mM})$ in the positive mode.

vides evidence of organic peroxide formation through aqueous photochemistry.

\section{Results and discussion}

\subsection{Standard solution (mixture of methylglyoxal and $t$-butyl hydroperoxide)}

FTICR-MS and FTICR-MS/MS analyses of the aqueous mixture of methylglyoxal and $t$-butyl hydroperoxide show methylglyoxal $\left(\mathrm{m} / \mathrm{z}^{+} 127.03666,145.04714\right.$ and 159.06278) and a peroxyhemiacetal (PHA ${ }_{\text {std }}$; $m / z^{+}$185.07797) in the positive mode (Fig. 3). In a mobile phase of $50 \% \mathrm{MeOH}$ and $50 \%$ water, methylglyoxal undergoes hydration with water and hemiacetal formation with $\mathrm{MeOH}$, and it is detected as a sodium adduct (i.e., $m / z^{+} 127.03666=[\text { methylglyoxal }+\mathrm{MeOH}+\mathrm{Na}]^{+}$, $m / z^{+} 145.04714=\left[\text { methylglyoxal }+\mathrm{H}_{2} \mathrm{O}+\mathrm{MeOH}+\mathrm{Na}\right]^{+}$,

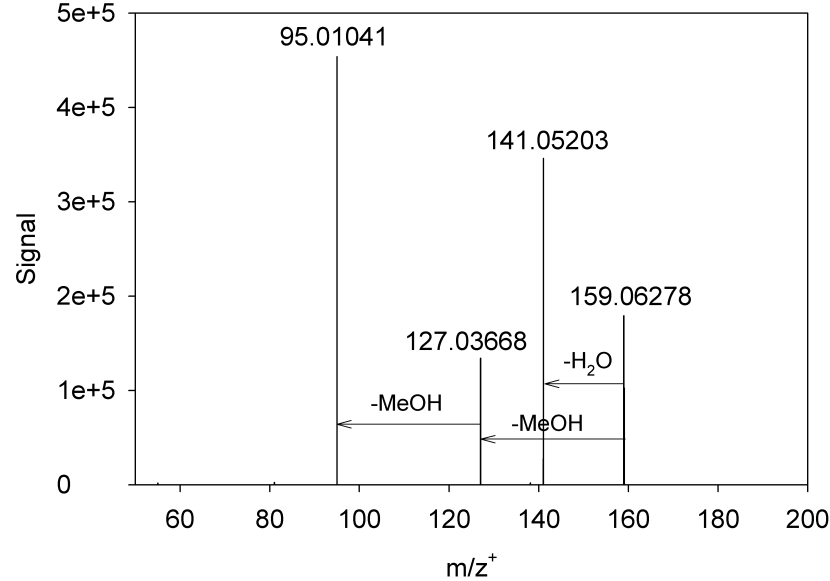

Figure 4. FTICR-MS/MS for $m / z^{+} 159$ (methylglyoxal).

and $m / z^{+} 159.06278=[\text { methylglyoxal }+2 \mathrm{MeOH}+\mathrm{Na}]^{+}$). Methylglyoxal solvation with $\mathrm{MeOH}$ was verified by FTICR-MS/MS (Fig. 4). The fragments of $m / z^{+} 159.06278$ are $m / z^{+} 141.05203\left(\mathrm{H}_{2} \mathrm{O}\right.$ loss), $m / z^{+} 127.03668(\mathrm{MeOH}$ loss), and $m / z^{+} 95.01041$ (another $\mathrm{MeOH}$ loss). The ion $m / z^{+} 95.01041$ is the sodium adduct to methylglyoxal (a theoretical reading for [methylglyoxal $+\mathrm{Na}]^{+}$is $\mathrm{m} / z^{+}$95.01090). We are confident that $\mathrm{m} / z^{+} 159.06278$ is a double hemiacetal of methanol with methylglyoxal, not a cluster of methylglyoxal with two methanol molecules, based upon the water loss in Fig. 4 and examination of ESI-MS standard runs for glyoxal and methylglyoxal in the water mobile phase with and without methanol (see Fig. S5 in the Supplement). A sodium adduct is also expected for peroxyhemiacetals and seen in Fig. 3 as $m / z^{+} 185.07797$ $\left(=\left[\mathrm{PHA}_{\text {std }}+\mathrm{Na}\right]^{+}\right)$. Details of FTICR-MS readings and theoretical readings based on actual molecular/atomic masses are shown in Table 1.

The PHA std $_{\text {peak, }} m / z^{+} 185.07802$ (theoretical reading of $\left[\mathrm{PHA}_{\mathrm{std}}+\mathrm{Na}\right]^{+}=185.07899$ ), was fragmented by infrared 
Table 2. FTICR-MS/MS and theoretical readings for fragments of peroxyhemiacetals and organic peroxides.

\begin{tabular}{c|c|c|c}
\hline Molecular ion & Fragment type & Theoretical reading & FTICR-MS / MS reading \\
\hline & Loss of $\mathrm{O}_{2}$ & {$\left[\mathrm{M}+\mathrm{Na}-\mathrm{O}_{2}\right]^{+}=81.06803$} & $\mathrm{~m} / \mathrm{z}^{+} 81.06971$ \\
\hline
\end{tabular}

multiphoton dissociation (IRMPD). Major fragments (Fig. 5) are $m / z^{+} 153.05228$ (MeOH loss) and $m / z^{+} 95.01041$ $\left([\text { methylglyoxal }+\mathrm{Na}]^{+}\right)$. In electron impact (hard ionization), fragmentation of organic peroxides results in the loss of $\mathrm{HO}_{2}$ (Tobias and Ziemann, 2000; Docherty et al., 2005). However, $\mathrm{O}_{2}$ loss is expected for soft ionization, IRMPD fragmentation in FTICR-MS/MS (M. Soule and E. Kujawinski, personal communication, 2013; detailed discussion in Supplement). In Fig. 5, the ion $m / z^{+} 81.06971$ indicates the loss of $\mathrm{O}_{2}$ from $t$-butyl hydroperoxide. We also observed

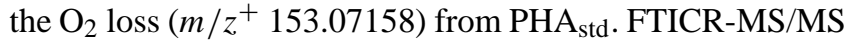
and theoretical readings are provided in Table 2.

Note that no organic peroxide peak was observed in the standard solution (nor in methylglyoxal $+\mathrm{OH}$ samples). This is not surprising because (1) high temperature of the capillary in an electrospray chamber $\left(\sim 250^{\circ} \mathrm{C}\right)$ is likely to decompose organic peroxides (Kharasch et al., 1950; M. Soule and E. Kujawinski, personal communication, 2013); (2) in the ESI method, it is difficult to ionize organic peroxides (Witkowski and Gierczak, 2013) and organic peroxides react with methylglyoxal to form peroxyhemiacetals. These peroxyhemiacetals are much more stable and less volatile than organic peroxides (Tobias and Ziemann, 2000). These peroxyhemiacetal peaks (and fragments) appear in FTICRMS (and FTICR-MS/MS) analysis of standard solutions and samples (see below), providing evidence of the presence (and formation) of organic peroxides from methylglyoxal $+\mathrm{OH}$. FTICR-MS/MS of peroxyhemiacetal peaks show corresponding organic peroxide fragments, methylglyoxal

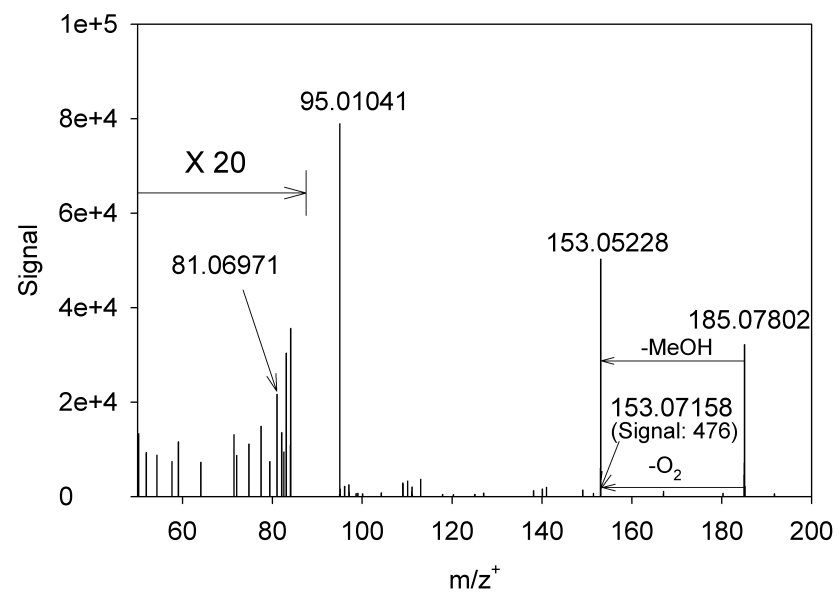

Figure 5. FTICR-MS/MS for $m / z^{+} 185\left(\mathrm{PHA}_{\text {std }}\right)$.

and other fragments as expected (Tobias and Ziemann, 2000; Docherty et al., 2005).

\subsection{Aqueous photooxidation products of methylglyoxal}

A FTICR mass spectrum of an aqueous methylglyoxal solution exposed to $\mathrm{OH}$ radicals for $60 \mathrm{~min}$ is shown in Fig. 6 (negative mode). Main photooxidation products (Tan et al., 2012; Lim et al., 2013) are seen at $m / z^{-} 87.00862$ (pyruvic acid) and $m / z^{-} 177.04036$ (2, 3-dimethyltartaric acid; structure shown in Fig. 6). This spectrum also provides evidence of peroxyhemiacetal formation at $m / z^{-} 163.02392$ 


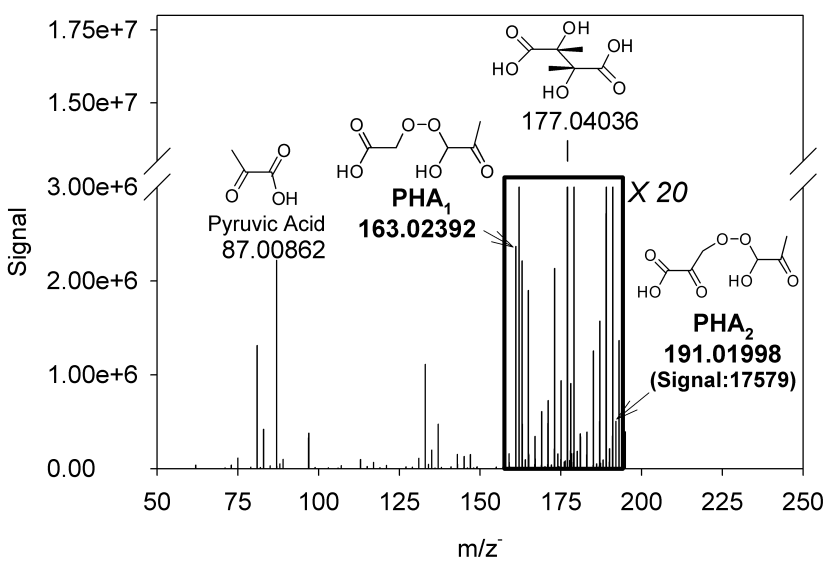

Figure 6. A full FTICR-MS spectrum for products of $1 \mathrm{~h}$ aqueous photooxidation of methylglyoxal in the negative mode.

$\left(=\left[\mathrm{PHA}_{1}-\mathrm{H}\right]^{-}\right)$and $m / z^{-} 191.01998\left(=\left[\mathrm{PHA}_{2}-\mathrm{H}\right]^{-}\right)$ since these readings are very close to the theoretical readings, $m / z^{-} 163.02405$ for $\mathrm{PHA}_{1}$ and $m / z^{-} 191.01918$ for $\mathrm{PHA}_{2}$ (Table 1). Fragmentation of these peaks by FTICRMS/MS supports their identification as peroxyhemiacetals. In Fig. 7a, $m / z^{-} 131.01339$ and $m / z^{-} 131.01585$ result from the losses of $\mathrm{MeOH}$ and $\mathrm{O}_{2}$, respectively, from $\mathrm{PHA}_{1}$ at $\mathrm{m} / \mathrm{z}^{-}$163.02405. $\mathrm{m} / \mathrm{z}^{-} 59.01377$ results from the loss of $\mathrm{O}_{2}$ from $\mathrm{R}_{1} \mathrm{OOH}$, which is the organic peroxide constituent of $\mathrm{PHA}_{1}$. Similarly, in Fig. 7b, $m / z^{-} 159.02946$ (C6H7O5) results from the loss of $\mathrm{O}_{2}$ from $\mathrm{PHA}_{2}$ at $m / z^{-} 191.02000$. $m / z^{-} 87.00832$ results from the loss of $\mathrm{O}_{2}$ from $\mathrm{R}_{2} \mathrm{OOH}$, which is the organic peroxide constituent of $\mathrm{PHA}_{2}$. Note that $m / z^{-} 191.02000$ is $\mathrm{PHA}_{2}$ while $m / z^{-} 191.05540$ is prominent as a parent ion. Due to the small intensity we were unable to isolate $\mathrm{m} / \mathrm{z}^{-} 191.02000$ from $\mathrm{m} / \mathrm{z}^{-} 191.05540$ for MS/MS analyses. Therefore, for the $\mathrm{PHA}_{2}$ analysis, we cannot rule out the possibility that $\mathrm{m} / \mathrm{z}^{-} 59.01377$ $\left[\mathrm{R}_{2} \mathrm{OOH}-\mathrm{O}_{2}\right]$ could be the fragment from $\mathrm{m} / \mathrm{z}^{-} 191.05540$ $\left[{\mathrm{C} 7 \mathrm{H} 11 \mathrm{O} 6]^{-}}^{-}\right.$. As was the case with the mixed peroxidealdehyde standard, the organic peroxides themselves were not observed (see previous section). Detected and theoretical readings are provided in Table 2 .

The FTICR-MS/MS was also conducted in the positive mode (Fig. 8) for PHA $_{1}\left(m / z^{+} 187.02069\right.$ in Fig. 8a) and $\mathrm{PHA}_{2}\left(\mathrm{~m} / \mathrm{z}^{+} 215.01565\right.$ in Fig. $\left.8 \mathrm{~b}\right)$. The theoretical readings are 187.02186 for $\mathrm{PHA}_{1}$ and 215.01678 for $\mathrm{PHA}_{2}$ (Table 1). The methylglyoxal fragments $\left(m / z^{+} 95.1041\right.$ in Fig. 8a and $m / z^{+} 95.0140$ in Fig. 8b) appear. This confirms that both $\mathrm{PHA}_{1}$ and $\mathrm{PHA}_{2}$ are indeed acid-catalyzed products of methylglyoxal. Note that for the $\mathrm{PHA}_{2}$ analysis in the positive mode, again, we cannot rule out the possibility that methylglyoxal $\left[\mathrm{m} / \mathrm{z}^{+} 95.01040\right]$ could be the fragment of $m / z 215.05151$ [C7H12O6Na] ${ }^{+}$.
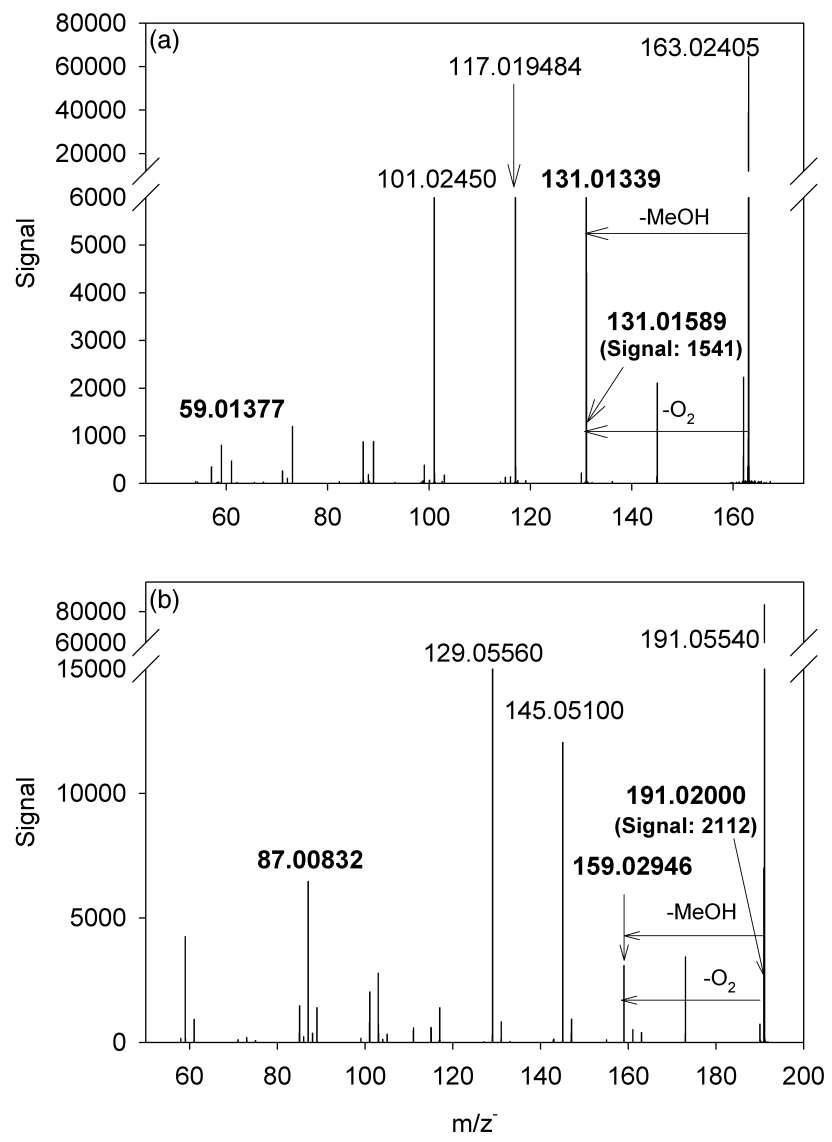

Figure 7. FTICR-MS/MS for $m / z^{-} 163$ for $\mathrm{PHA}_{1}$ (a) and $m / z^{-} 191 \mathrm{PHA}_{2}$ (b).

\section{Atmospheric implications}

Using ultra-high-resolution FTICR-MS and FTICR-MS/MS, we observed the presence of peroxyhemiacetals, after aqueous photooxidation of methylglyoxal and in aqueous methylglyoxal-organic peroxide standard solutions. The presence of stable peroxyhemiacetals is an indicator of the existence of the less stable organic peroxides. Thus, this work provides evidence of the formation of organic peroxides through aqueous-phase $\mathrm{OH}$ radical oxidation of methylglyoxal.

\subsection{Organic peroxide production in clouds and wet aerosols}

Below we demonstrate through chemical modeling that organic peroxides photochemically form from organics present both in clouds and wet aerosols. We used the full kinetic model for glyoxal and methylglyoxal (Lim et al., 2013) to simulate the formation of organic peroxides and peroxyhemiacetals. The following updates were made to the model: (1) the rate constant for the bimolecular reactions of $\mathrm{RO}_{2}$ and $\mathrm{HO}_{2}$ was given as $3 \times 6 \mathrm{M}^{-1} \mathrm{~s}^{-1}$ (Reactions R213- 

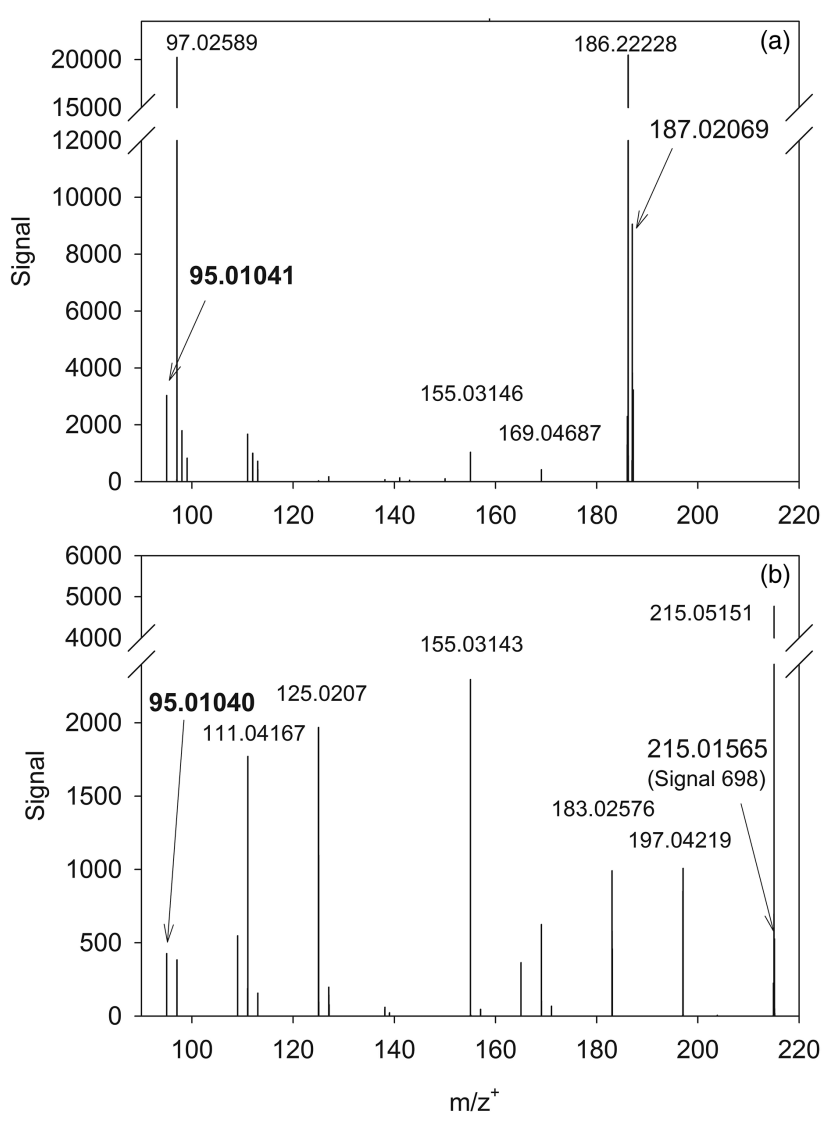

Figure 8. FTICR-MS/MS for $m / z^{+} 187$ for $\mathrm{PHA}_{1}$ (a) and $m / z^{+} 215$ for $\mathrm{PHA}_{2}$ (b).

R219 in Table $\mathrm{S} 1$ in the Supplement) based on the rate constant for $\left[\mathrm{HO}_{2}+\mathrm{HO}_{2}\right] \sim 1 \times 6 \mathrm{M}^{-1} \mathrm{~s}^{-1}$; (2) the concentration of $\mathrm{OH}$ in the aqueous phase was set to $\sim 10^{-14}$ (previously $\sim 10^{-12}$ ) according to recent estimations (Arakaki et al., 2013) (Fig. S1a); (3) the concentration of $\mathrm{HO}_{2}$ photochemically formed in the aqueous phase was estimated to be $\sim 10^{-8} \mathrm{M}$ maintained by the Henry's law equilibrium; therefore, the excess $\mathrm{HO}_{2}$ produced by photooxidation in the aqueous phase was transported to the gas phase (Fig. S1b). All the reactions included in the model are listed in Table S1.

For wet-aerosol simulations, $1 \mathrm{M}$ (the initial concentration) of methylglyoxal was used in the aqueous phase. Note that we do not expect that methylglyoxal is present at $1 \mathrm{M}$ in aerosols. However, water-soluble organic matter is present at $1-10 \mathrm{M}$. So this analysis treats all watersoluble organic matter as if it behaves like methylglyoxal. Under wet-aerosol conditions ([methylglyoxal $]_{\text {initial }}=1 \mathrm{M}$, $\left[\mathrm{H}_{2} \mathrm{O}_{2}\right]_{\text {initial }}=0 \mathrm{M},[\mathrm{OH}] \sim 10^{-14} \mathrm{M}$, and $\left[\mathrm{HO}_{2}\right] \sim 10^{-8} \mathrm{M}$ ), $\sim 400 \mu \mathrm{M}$ of organic peroxides during the $12 \mathrm{~h}$ daytime were formed through aqueous $\mathrm{OH}$ radical reactions (Fig. 10a). The model also includes the sinks of aqueous-phase organic peroxides: OH radical reactions (Reactions R220-R225), photolysis (Reaction R230), and the evaporation to the gas

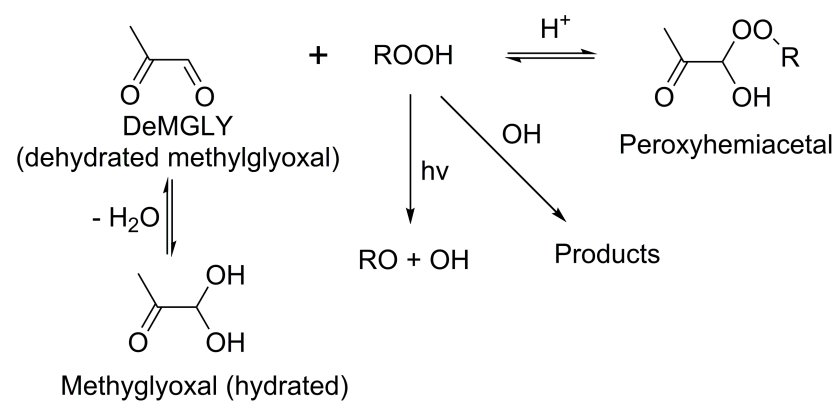

Figure 9. Peroxyhemiacetal formation.

phase (Reaction R234) in Table S1. Note that organic peroxide (ROOH) formation in Fig. 10a and $b$ does not change within the Henry's law constant, 100 to $1000 \mathrm{M} \mathrm{atm}^{-1}$, and the evaporation rate is assumed to be a diffusion-controlled transfer coefficient (Lelieveld and Crutzen, 1991; Lim et al., 2005), which is the upper limit based on the equation provided by Lelieveld and Crutzen (1991). Here, the gas-phase $[\mathrm{ROOH}]$ is assumed to be $1 \mathrm{ppb}$ (Reaction R234 in Table S1).

In atmospheric cloud conditions ([methylglyoxal $]_{\text {initial }}=$ $10 \mu \mathrm{M},\left[\mathrm{H}_{2} \mathrm{O}_{2}\right]_{\text {initial }}=0 \mathrm{M},[\mathrm{OH}] \sim 10^{-14} \mathrm{M}$, and $\left[\mathrm{HO}_{2}\right] \sim$ $\left.10^{-8} \mathrm{M}\right), \sim 0.4 \mu \mathrm{M}$ of organic peroxide formation during the $12 \mathrm{~h}$ daytime is expected (Fig. 10b) while all the sinks of organic peroxides listed above are included. This concentration of aqueous-phase photochemically produced organic peroxides is within the range of measured rainwater concentrations $(0.1-10 \mu \mathrm{M})$ and similar to the concentration expected by Henry's law equilibrium from gas-phase organic peroxides (0.1-1 ppb).

\subsection{Peroxyhemiacetal formation in wet aerosol}

The formation of peroxyhemiacetals competes with (1) hydration of methylglyoxal and (2) photolysis and $\mathrm{OH}$ reactions of organic peroxides (Fig. 9). Competing with methylglyoxal hydration means that only a dehydrated methylglyoxal (DeMGLY), not hydrated methylglyoxal (MGLY), forms a peroxyhemiacetal (PHA) with an organic peroxide $(\mathrm{ROOH})$, since the aldehyde reacts with peroxides. The dehydration equilibrium for methylglyoxal is included in the model (Reaction R226 in Table S1). In wet aerosols, $\sim 0.4 \mathrm{mM}$ of DeMGLY out of $1 \mathrm{M}$ MGLY will undergo peroxyhemiacetal formation and react with $\mathrm{OH}$ radicals (Reactions R227 and R228 in Table S1) at the same time (Fig. S2a). The main sink for peroxyhemiacetals is expected to be $\mathrm{OH}$ reaction (no evaporation is expected). The peroxyhemiacetal formation equilibrium (Reaction R229) and the $\mathrm{OH}$ reaction of peroxyhemiacetals (Reaction R231) are listed in Table S1. The modified model simulates $\sim 0.4 \mu \mathrm{M}$ of peroxyhemiacetal formation during the $12 \mathrm{~h}$ daytime and the minor increase during the nighttime (Fig. 10a). Under cloud conditions, peroxyhemiacetal formation is negligible (note that the model simulates $\sim 4 \times 10^{-15} \mathrm{M}$ peroxyhemiacetal formation during 


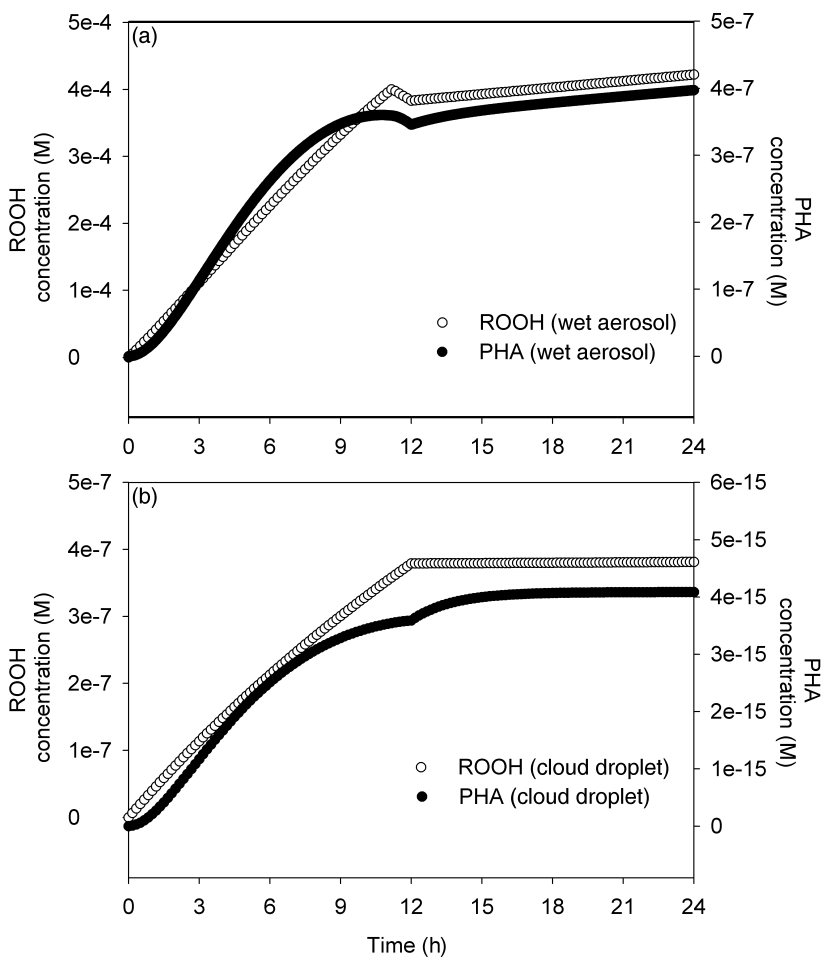

Figure 10. The simulated atmospheric concentrations of ROOH (organic peroxides) and PHA (peroxyhemiacetals) in wet aerosols (a) and cloud droplets (b) during $24 \mathrm{~h}$. The first $12 \mathrm{~h}$ are daytime.

the daytime from $10 \mu \mathrm{M}$ of methylglyoxal photooxidation in Fig. 10b).

\subsection{OH recycling due to the photolysis of organic peroxides in atmospheric waters}

In both cloud and wet-aerosol conditions, $7.5 \times 10^{-15} \mathrm{M}$ of aqueous-phase $\mathrm{OH}$ production is expected from the photolysis of organic peroxides $\left([\mathrm{ROOH}]_{\text {initial }} \sim 400 \mu \mathrm{M}\right.$ in wet aerosols and $[\mathrm{ROOH}]_{\text {initial }} \sim 0.4 \mu \mathrm{M}$ in cloud droplets) formed by aqueous photooxidation during the $12 \mathrm{~h}$ daytime (Fig. S3) while the sink of $\mathrm{ROOH}$ is $\mathrm{OH}$ reaction. Note that Badali et al. (2015) confirmed OH formation from photolysis of solutions of organic peroxide $\mathrm{SOA}$ and that measured $\mathrm{OH}$ formation rates are comparable to an estimation by Arakaki et al. (2013), which is $\sim 10^{-14} \mathrm{M} \mathrm{OH}$ in atmospheric waters; $\sim 10^{-14}-10^{-15} \mathrm{M}$ of $\mathrm{OH}$ was previously estimated in the core of the bulk phase (Jacob, 1986). Thus, the aqueous production of organic peroxides in atmospheric waters could be an important source of aqueous $\mathrm{OH}$ through organic peroxide photolysis.

The Supplement related to this article is available online at doi:10.5194/acp-15-12867-2015-supplement.
Acknowledgements. This research has been supported in part by the National Science Foundation (grants 1052611) and the US Environmental Protection Agency's Science to Achieve Results (STAR) program (grant 83541201). The work has not been subjected to any federal agency review and therefore does not necessarily reflect the views of the EPA or NSF; no official endorsement should be inferred. We acknowledge Melissa C. Kido Soule, Elizabeth B. Kujawinski and the funding sources of WHOI FT-MS Users' Facility (National Science Foundation OCE-0619608 and the Gordon and Betty Moore Foundation). We also thank Paul J. Ziemann for helpful discussions.

Edited by: M. Ammann

\section{References}

Aiken, A. C., DeCarlo, P. F., Kroll, J. H., Worsnop, D. R., Huffman, J. A., Docherty, K.,Ulbrich, I. M., Mohr, C., Kimmel, J. R., Sueper, D., Zhang, Q., Sun, Y., Trimborn, A., Northway, M., Ziemann, P. J., Canagaratna, M. R., Onasch, T. B., Alfarra, R., Prevot, A. S. H., Dommen, J., Duplissy, J., Metzger, A., Baltensperger, U., and Jimenez, J. L.: O/C and OM/OC Ratios of Primary, Secondary, and Ambient Organic Aerosols with High Resolution Time-of-Flight Aerosol Mass Spectrometry, Environ. Sci. Technol., 42, 4478-4485, 2008.

Altieri, K. E., Seitzinger, S. P., Carlton, A. G., Turpin, B. J., Klein, G. C., and Marshall, A. G.: Oligomers Formed through InCloud Methylglyoxal Reactions: Chemical Composition, Properties, and Mechanisms Investigated by Ultra-High Resolution FT-ICR Mass Spectrometry, Atmos. Environ., 42, 1476-1490, 2008.

Andreae, M. O. and Gelencsér, A.: Black carbon or brown carbon? The nature of light-absorbing carbonaceous aerosols, Atmos. Chem. Phys., 6, 3131-3148, doi:10.5194/acp-6-3131-2006, 2006.

Arakaki, T. and Faust, B. C.: Sources, Sinks, and Mechanisms of Hydroxyl Radical $(\mathrm{OH})$ Photoproduction and Consumption in Authentic Acidic Continental Cloud Waters From Whiteface Mountain, New York: The Role of the Fe(R) (R= II, III) Photochemical Cycle, J. Geophys. Res., 103, 3487-3504, 1998.

Arakaki, T., Anastasio, C., Kuroki, Y., Nakjima, H., Okada, K., Kotani, Y., Handa, D., Azechi, S., Kimura, T., Tsuhako, A., and Miyagi, Y.: A General Scavenging Rate Constant for Reaction of Hydroxyl Radical with Organic Carbon in Atmospheric Waters, Environ. Sci. Technol., 47, 8196-8203, 2013.

Atkinson, R. and Arey, J.: Atmospheric Degradation of Volatile Organic Compounds, Chem. Rev., 103, 4605-4638, 2003.

Badali, K. M., Zhou, S., Aljawhary, D., Antiñolo, M., Chen, W. J., Lok, A., Mungall, E., Wong, J. P. S., Zhao, R., and Abbatt, J. P. D.: Formation of hydroxyl radicals from photolysis of secondary organic aerosol material, Atmos. Chem. Phys., 15, 7831-7840, doi:10.5194/acp-15-7831-2015, 2015.

Blando, J. D. and Turpin B. J.: Secondary Organic Aerosol Formation in Cloud and Fog Droplets: A Literature Evaluation of Plausibility, Atmos. Environ., 34, 1623-1632, 2000.

Bones, D. L., Henricksen, D. K., Mang S. A., Gonsior, M., Bateman, A. P., Nguyen, T. B., Cooper, W. J., and Nizkorodov, S. A. Appearance of Strong Absorbers and Fluorophores in Limonene- 
$\mathrm{O}_{3}$ Secondary Organic Aerosol Due to $\mathrm{NH}_{4}^{+}$-Mediated Chemical Aging Over Long Time Scales, J. Geophys. Res., 115, D05203, doi:10.1029/2009JD01864, 2010.

Carlton, A. G., Turpin, B. J., Altieri, K. E., Seitizinger, S. P., Mathur, R., Roselle, S. J., and Weber, R. J.: CMAQ Model Performance Enhanced When In-Cloud Secondary Organic Aerosol is Included: Comparisons of Organic Carbon Predictions with Measurements, Environ. Sci. Technol., 42, 8798-8802, 2008.

Carlton, A. G. and Turpin, B. J.: Particle Partitioning Potential of Organic Compounds is Highest in the Eastern US and Driven by Anthropogenic Water, Atmos. Chem. Phys., 13, 10203-10214, doi:10.5194/acp-13-10203-2013, 2013.

Chen, J., Griffin, R. J., Grini, A., and Tulet, P.: Modeling secondary organic aerosol formation through cloud processing of organic compounds, Atmos. Chem. Phys., 7, 5343-5355, doi:10.5194/acp-7-5343-2007, 2007.

De Serves, C.: Gas Phase Formaldehyde and Peroxide Measurements in the Artic Atmosphere, J. Geophys. Res., 99, 5471-5483, 1994.

Dibble, T. S.: Failures and Limitations of Quantum Chemistry for Two Key Problems in the Atmospheric Chemistry of Peroxy Radicals, Atmos. Environ., 42, 5837-5848, 2007.

Docherty, K. S., Wu, W., Lim, Y. B., and Ziemann, P. J.: Contribution of Organic Peroxides to Secondary Organic Aerosol Formed from Reactions of Monoterpenes with $\mathrm{O}_{3}$, Environ. Sci. Technol., 39, 4049-4059, 2005.

Ehn, M., Thornton, J. A., Kleist, E., Sipila, M., Junninen, H., Pullinen, I., Springer, M., Rubach, F., Tillmann, R., Lee, B., Lopez-Hilfiker, F., Andres, S., Acir, I., Rissanen, M., Jokinen, T., Schobesberger, S., Kangasluoma, J., Kontkanen, J., Nieminen, T., Kurten, T., Nielsen, L., Jorgensen, S., Kjaegaard, H. G., Canagaratna, M., Maso, M. D., Berndt, T., Petaja, T., Wahner, A., Kerminen, V., Kulmala, M., Worsnop, D. R., Wildt, J., and Mentel, F.: A Large Source of Low-Volatility Secondary Organic Aerosol, Nature, 506, 476-479, 2014.

Ervens, B., Sorooshian, A., Lim, Y. B., Turpin, B. J.: Key Parameters Controlling OH-Initiated Formation of Secondary Organoc Aerosol in the Aqueous Phase (aqSOA), J. Geophys. Res.Atmos., 119, 3997-4016, 2014.

Faust, B. C. and Allen, J. M.: Aqueous-Phase Photochemical Formation of Hydroxyl Radical in Authentic Cloudwaters and Fogwaters, Environ. Sci. Technol., 27, 1221-1224, 1993.

Fu, T-M., Jacob, D. J., Wittrock, F., Burrows, J. P., Vrekoussis, M., and Henze, D. K.: Global Budgets of Atmospheric Glyoxal and Methylglyoxal, and Implications for Formation of Secondary Organic Aerosols, J. Geophys. Res., 113, D15303, doi:10.1029/2007JD009505, 2008.

Glowacki, D. R., Lockhart, J., Blitz, M. A., Klippenstein, S. J., Piling, M. J., Robertson, S. H., and Seakins, P. W.: Interception of Excited Vibrational Quantum States by $\mathrm{O}_{2}$ in Atmospheric Association Reactions, Science, 337, 1066-1069, 2012.

Grossmann, D., Moortgat, G. K., Kibler, M., Schlomski, S., Bachmann, K., Alicke, B., Geyer, A., Platt, U., Hammer, M.-U., and Vogel, B.: Hydrogen Peroxide, Organic Peroxides, Carbonyl Compounds and Organic Acids Measured at Pabstthum during BERLIOZ, J. Geophys. Res., 108, 8250, doi:10.10292001JD001096, 2003.

Guo, J., Tilgner, A., Yeung, C., Wang, Z., Louie, P. K. K., Luk, C. W. Y., Xu, Z., Yuan, C., Gao, Y., Poon, S., Herrmann, H.,
Lee, S., Lam, K. S., and Wang, T.: Atmospheric Peroxides in a Polluted Subtropical Environment: Seasonal Variation, Sources and Sinks, and Importance of Heterogeneous Processes, Environ. Sci. Technol., 48, 1443-1460, 2014.

Hellpointer, E. and Gab, S.: Detection of Methyl, Hydroxymethyl and Hydroxyethyl Hydroperoxides in air and precipitation, Nature, 337, 631-634, 1989.

Henze, D. K., Seinfeld, J. H., Ng, N. L., Kroll, J. H., Fu, T.-M., Jacob, D. J., and Heald, C. L.: Global modeling of secondary organic aerosol formation from aromatic hydrocarbons: highvs. low-yield pathways, Atmos. Chem. Phys., 8, 2405-2420, doi:10.5194/acp-8-2405-2008, 2008.

Jacob, D. J.: Chemistry of $\mathrm{OH}$ in Remote Clouds and Its Role in the Production of Formic Acid and Peroxymonosulfate, J. Geophys. Res., 91, 9807-9826, 1986.

Kanakidou, M., Seinfeld, J. H., Pandis, S. N., Barnes, I., Dentener, F. J., Facchini, M. C., Van Dingenen, R., Ervens, B., Nenes, A., Nielsen, C. J., Swietlicki, E., Putaud, J. P., Balkanski, Y., Fuzzi, S., Horth, J., Moortgat, G. K., Winterhalter, R., Myhre, C. E. L., Tsigaridis, K., Vignati, E., Stephanou, E. G., and Wilson, J.: Organic aerosol and global climate modelling: a review, Atmos. Chem. Phys., 5, 1053-1123, doi:10.5194/acp-5-1053-2005, 2005.

Kharasch, M. S., Fono, A., and Nudenberg, W.: The Chemistry o Hydroperoxides, VI. The Thermal Decomposition of $\alpha$-Cumyl Hydroperoxide, J. Org. Chem., 15, 748-752, 1950.

Lee, J. H., Leahy, D. F., Tang, I. N., and Newman, L. Measurement and Speciation of Gas-Phase Peroxides in the Atmosphere, J. Geophys. Res., 98, 2911-2915, 1993.

Lee, M., Heikes, B. G., and O'Sullivan, D. W.: Hydrogen Peroxide and Organic Hydroperoxide in the Troposphere: a Review, Atmos. Environ., 34, 3475-3494, 2000.

Lelieveld, J. and Crutzen, P. J.: The Role of Clouds in Tropospheric Photochemistry, J. Atmos. Chem., 12, 229-267, 1991.

Liang, H., Chen, Z. M., Huang, D., Zhao, Y., and Li, Z. Y.: Impacts of aerosols on the chemistry of atmospheric trace gases: a case study of peroxides and $\mathrm{HO}_{2}$ radicals, Atmos. Chem. Phys., 13, 11259-11276, doi:10.5194/acp-13-11259-2013, 2013.

Lim, H. J., Carlton, A. G., and Turpin, B. J.: Isoprene forms secondary organic aerosol through cloud processing: model simulations, Environ. Sci. Techol., 39, 4441-4446, 2005.

Lim, Y. B., Tan, Y., Perri, M. J., Seitzinger, S. P., and Turpin, B. J.: Aqueous chemistry and its role in secondary organic aerosol (SOA) formation, Atmos. Chem. Phys., 10, 1052110539, doi:10.5194/acp-10-10521-2010, 2010.

Lim, Y. B., Tan, Y., and Turpin, B. J.: Chemical insights, explicit chemistry, and yields of secondary organic aerosol from $\mathrm{OH}$ radical oxidation of methylglyoxal and glyoxal in the aqueous phase, Atmos. Chem. Phys., 13, 8651-8667, doi:10.5194/acp-13-86512013, 2013.

Lin, G., Penner, J. E., Sillman, S., Taraborrelli, D., and Lelieveld, J.: Global modeling of SOA formation from dicarbonyls, epoxides, organic nitrates and peroxides, Atmos. Chem. Phys., 12, 47434774, doi:10.5194/acp-12-4743-2012, 2012.

Lind, J. A. and Kok, G.: Henry's Law Determinations for Aqueous Solutions of Hydrogen Peroxide, Methylhydroperoxide, and Peroxyacetic Acid, J. Geophys. Res., 91, 7889-7895, 1986.

Liu, J., Horowitz, L. W., Fan, S., Carlton, A. G., and Levy II, H.: Global In-Cloud Production of Secondary Organic Aerosols: 
Implementation of a Detailed Chemical in the GFDL Atmospheric Model AM3, J. Geophys. Res., 117, D15303, doi:10.1029/2012JD017838. 2012a.

Liu, Y., Monod, A., Tritscher, T., Praplan, A. P., DeCarlo, P. F., Temime-Roussel, B., Quivet, E., Marchand, N., Dommen, J., and Baltensperger, U.: Aqueous phase processing of secondary organic aerosol from isoprene photooxidation, Atmos. Chem. Phys., 12, 5879-5895, doi:10.5194/acp-12-5879-2012, 2012 b.

Long, Y., Charbouillot, T., Brigante, M., Maihot, G., Delort, A.-M., Chaumerliac, N., and Deguillaume, L.: Evaluation of Modeled Cloud Chemistry Mechanism against Laboratory Irradiation Experiments: The HxOx/Iron/Carboxylic Acid Chemical System, Atmos. Environ., 77, 686-695, 2013.

McNeill, V. F., Woo, J. L., Kim, D. D., Schwier, A. N., Wannell, N. J., Sumner, A. J., and Barakt, J. M.: Aqueous-Phase Secondary Organic Aerosol and Organosulfate Formation in Atmospheric Aerosols: A Modeling Study, Environ. Sci. Technol., 46, 80758081, 2012.

Paulot, F., Crounse, J. D., Kjaergaard, H. G., Kurten, A., Clair, J. M. St., Seinfeld, J. H., and Wennberg, P. O.: Unexpected Epoxide Formation in the Gas-Phase Photooxidation of Isoprene, Science, 325, 730-733, 2009.

Sauer, F., Beck, J., Schuster, G., and Moortgat, G. K.: Hydrogen Peroxide, Organic Peroxides and Organic Acids in a Forest Area During FIELDVOC'94, Chemosphere Global Change Sci., 3, 309-326, 2001,

Seinfeld, J. H. and Pandis, S. N.: Atmospheric Chemistry and Physics, 1st Edn., Wiley-Interscience, New York, 1998.

Singh, H., Kanakidou, M., Crutzen, P. J., and Jacob, D. J.: High Concentrations and photochemical fate of oxygenated hydrocarbons in the global troposphere, Nature, 2, 50-54, 1995.

Tan, Y., Carlton, A. G., Seitzinger, S. P., and Turpin, B. J.: SOA from methylglyoxal in clouds and wet aerosols: measurements and prediction of key products, Atmos. Environ., 44, 5218-5226, 2010.

Tan, Y., Lim, Y. B., Altieri, K. E., Seitzinger, S. P., and Turpin, B. J.: Mechanisms leading to oligomers and SOA through aqueous photooxidation: insights from $\mathrm{OH}$ radical oxidation of acetic acid and methylglyoxal, Atmos. Chem. Phys., 12, 801-813, doi:10.5194/acp-12-801-2012, 2012.

Taraborrelli, D., Lawrence, M. G., Crowley, J. N., Dillon, T. J., Gromov, S., Groß, C. B. M., Vereecken, L., and Lelieveld, J.: Hydroxyl Radical Buffered by Isoprene Oxidation over Tropical Forests, Nat. Geosci., 5, 190-193, 2012.

Tobias, H. J. and Ziemann, P. J.: Thermal Desorption Mass Spectrometric Analysis of Organic Aerosol Formed from Reactions of 1-Tetradecene and $\mathrm{O}_{3}$ in the Presence of Alcohols and Carboyxlic Acids, Environ. Sci. Technol., 34, 2105-2115, 2000.
Weller, C., Tilgner, A., Brauer, P., and Herrmann, H.: Modeling the Impact of Iron-Carboxylate Photochemistry on Radical Budget and Carboxylate Degradation in Cloud Droplet and Particles, Environ. Sci. Technol., 48, 5652-5659, 2014.

Wennberg, P. O., Hanisco, T. F., Jaegle, L., Jacob, D. J., Histsa, E. J., Lanzendorf, E. J., Anderson, J. G., Gao, R.-S., Kelm E. R., Donnelly, S. G., Del Negro, L. A., Fahey, D. W., McKeen, S. A., Salawitch, R. J., Webster, C. R., May, R. D., Herman, R. L., Proffit, M. H., Margitan, J. J., Atlas, E. L., Schauffler, S. M., Flocke, F., EmElroy, C. T., and Bui, T. P.: Hydrogen Radicals, Nitrogen Radicals, and the Production of $\mathrm{O}_{3}$ in the Upper Troposphere, Science, 279, 49-53, 1998.

Witkowski, B. and Gierczak, T.: Analysis of $\alpha$ Acyloxyhydroperoxy Aldehydes with Electrospray IonizationTandem Mass Spectrometry (ESI-MS ${ }^{n}$ ), J. Mass Spectrom., 48, 79-88, 2013.

Zhang, Q., Jimenez, J. L., Canagaratna, M. R., Allan, J. D., Coe, H., Ulbrich, I., Alfarra, M. R., Takami, A., Middlebrook, A M., Sun, Y. L., Dzepina, K., Dunlea, E., Docherty, K., DeCarlo, P. F., Salcedo, D., Onasch, T., Jayne, J. T., Miyoshi, T., Shimono, A., Hatakeyama, S., Takegawa, N., Kondo, Y., Schneider, J., Drewnick, F., Weimer, S., Demerjian, K., Williams, P., Bower, K., Bahreini, R., Cottrell, L., Griffin, R. J., Rautiainen, J., and Worsnop, D. R.: Ubiquity and Dominance of Oxygenated Species in Organic Aerosols in Anthropogenically-Influenced Northern Hemisphere Mid-Latitudes, Geophys. Res. Lett., 34, L13801, doi:10.1029/2007GL029979, 2007.

Zhang, X., Lin, Y.-H., Surratt, J. D., Zotter, P., Prevot, A. H. S., and Weber, R. J.: Light-Absorbing Soluble Organic Aerosol in Los Angeles and Atlanta: A Contrast in Secondary Organic Aerosol, Geophys. Res. Lett., 38, L21810, doi:10.1029/2011GL049385, 2011.

Zhao, R., Lee, A. K. Y., Soong, R., Simpson, A. J., and Abbatt, J. P. D.: Formation of aqueous-phase $\alpha$-hydroxyhydroperoxides $(\alpha$ HHP): potential atmospheric impacts, Atmos. Chem. Phys., 13, 5857-5872, doi:10.5194/acp-13-5857-2013, 2013.

Ziemann, P. J.: Evidence of Low-Volatility Diacyl Peroxides as a Nucleating Agent and Major Component of Aerosol Formed from Reactions of $\mathrm{O}_{3}$ with Cyclohexene and Homologous Compounds, J. Phys. Chem. A, 106, 4390-4402, 2002. 